DOI: https://doi.org/10.31933/dijemss.v2i3

Received: $30^{\text {th }}$ December 2020, Revised: $15^{\text {th }}$ January 2021, Publish: $3^{\text {nd }}$ March 2021

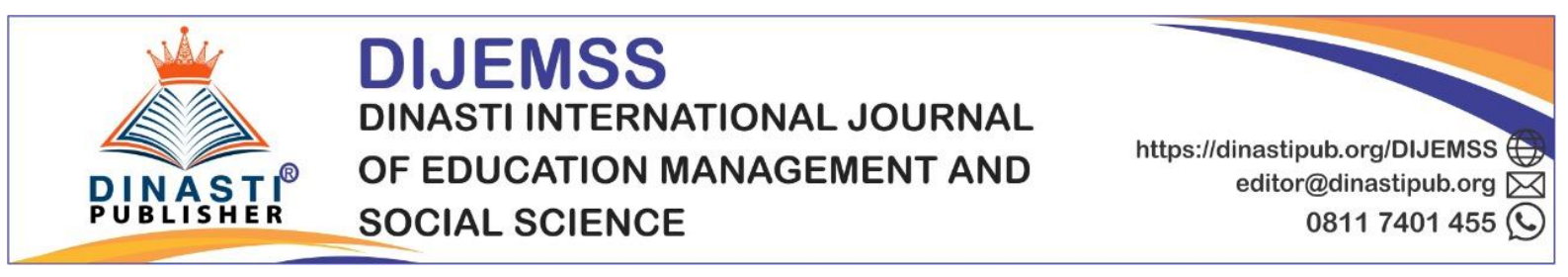

\title{
THE MODEL OF PATIENT SATISFACTION AND TRUST: A STUDY AT BPJS PATIENT
}

\author{
Peni Cahyati ${ }^{1}$ \\ ${ }^{1)}$ Politeknik Kesehatan Kementrian Kesehatan, Tasikmalaya, Indonesia, \\ peni_poltekestsm@yahoo.com
}

Corresponding Author: Peni Cahyati ${ }^{1}$

\begin{abstract}
Health is a major requirement for every resident living in this world, and health development essentially concerns both physical and mental health. The state of health of a person will be influential on the aspects of social life is economic, and the continuity of the life of a nation and a country anywhere in the world, both in countries that have developed and in developing countries such as Indonesia as well as health is a right and an investment for all citizens of Indonesia. The research method uses descriptive analysis and verification analysis. By using a combination of analytical methods can be obtained by generalizing that is comprehensive. Samples taken as many as 100 patients BPJS health center Purbaratu Tasikmalaya City and sampling was done randomly or random sampling. Data analysis used is SEM (Stucture Equation Model). Based on the results of the research can be known that there are degrees of contribution of the variable provision of a service to trust patients through the patient satisfaction. The better the delivery of services provided by the health center Purbaratu Tasikmalaya City the better satisfaction of the patients received that will ultimately have an impact on the increased confidence of the patient to the health center Purbaratu the City of Tasikmalaya.
\end{abstract}

Keyword: The Provision of Services, Patient Satisfaction, Patient Trust.

\section{INTRODUCTION}

Health was a investment for the community, because health is the basic capital which is needed by the whole community to be able to work in accordance with the duties and responsibilities of each, so as to produce something useful for yourself and family. However, if the condition of the health problem is not not possible the entire property and wealth will be used up to acquire the health.

The law of the Republic of Indonesia Number 23 year 1992 on the Basis of Health stated that the health of the people is one of the principal capital in the framework of the growth of the nation and has an important role in the completion of the National health and preparation of the people of Indonesia. So the government should pursue the field of health with the best, to provide adequate health services and can be accessed easily by the general public. 
Indonesia, particularly in the set of health problems, required a special body responsible in organizing the health insurance, the National Social security System (SJSN) is a Social security System organized by the government to ensure its citizens to meet the basic needs of life are feasible, as in the UN Declaration on Human Rights (human RIGHTS) of 1948 and ILO Convention No. 1021952 (Kemenkes RI 2012, 2012). The agency must provide a good quality service in order to achieve the satisfaction of service that is consistent with the objectives of the World Health Organization in developing the best health for all the population.

The legal basis of the establishment of BPJS Health is 1). Act of 1945, Amendment II of the CONSTITUTION 45 Article $28 \mathrm{H}$ paragraph 3 states everyone is entitled to a social security that allows the development of oneself fully as a dignified human, 2). Law Number 40 Year 2004 on National Social security System, 3). Law No. 24 Year 2011 regarding Social security Agency, in the management of the BPJS Health, management based on good governance, among others: 1). General guidelines for the Good Governance of BPJS Health, 2). Board Manual BPJS Health, and 3). The code of Ethics of the BPJS Health (Suprianto \& Mutiarin, 2017).

First-level health facilities (FKTP) can be either a health center or equivalent, doctors ' practices, dentist, clinic, primary or its equivalent, and Hospital Grade D Primary or the equivalent, while the health facilities referral advanced level (FKRTL) specialized clinic main or equivalent, general hospital, and special hospital (Suprianto \& Mutiarin, 2017).

(Gouws et al., 2005) Some of the complaints of Health Facilities (public facilities) against the cooperation with BPJS Health 2017, as summarized in Rakerkesnas, 01 March 2017, among others 1). The distribution of participants in FKTP uneven, 2). Many participants registered in the public facilities specific, 3). Drug empty in the Distributor, 4). The process of filing a claim long, 5). The process of working public facilities is not transparent, 6). The patient does not understand the service procedure, 7). Rates of Capitation and INACBG inadequate, 8). Too many application that should be entered, and 9). The distribution of Participants in FKTP uneven, many participants registered in the public facilities specific.

The ministry of Health of the Republic of Indonesia Year 2017 states the implementation of health services comprehensive, for Health Facilities that do not have means of support is obliged to build networks with supporting infrastructure. First-level health facilities that do not have means of pharmacy and also can not show evidence of cooperation by means of the pharmaceutical will not be able to cooperate with BPJS Health (Suprianto \& Mutiarin, 2017).

The issuance of Presidential Regulation (Perpres) No. 182016 on the Second amendment to Presidential Regulation No. 12 Year 2014 about Health insurance, make polemic new in the community. with the regulation contribution participant workers not wage earners (PBPU) and participants are not workers increased. For the participants of the III class, the fee that was Rp25.500 per month/person to Rp30.000. The increase is higher in class II and I. For class II, the dues of the previous Rp42.500 to Rp51.000. While in class I to Rp80.000 from the previous Rp59.500.

The Indonesian Consumers foundation (YLKI) said that the increase in dues is not right if we look in the mirror with the conditions of service in the field. For YLKI, up to this JKN program managed by Health BPJS not have minimum service standards that are clear, in almost all lines of services of the BPJS is still very disappointing for the public (Rolindrawan, 2015). 
(Suprianto \& Mutiarin, 2017) states users of health care services including Clinic always pay attention to the quality of the medical staff, emergency services, nurse care, the availability of complete services, the recommendations of doctors, modern equipment, employee courtesy, good environment, the use of the previous hospital, cost of care, the recommendations of the family, near of the house, the room is private and the recommendation of a friend.

Based on the background mentioned above, the researcher interested to know and investigate more about the delivery of services, patient satisfaction has to do with the trust of the patient. The title of the proposed research is : "the Effect of the Provision of Services To the Satisfaction of the Patient as well As the Implications On the Trust the Patient BPJS Puskesmas Purbaratu the City of Tasikmalaya".

\section{LITERATURE REVIEW Management}

Management is something that is absolutely implemented by an organization or company which has an important role in managing, organizing, utilizing resources so that the expected goals and set previously can be achieved effectively and efficiently.

Need to know what is meant by Management. (Mangkunegara, 2003) said: "Management is the process of planning, organising, leading and controlling the work of organization members and of using all organizational resources to achieve organizational goals that have been defined".

According to (Marwansyah, 2012) says that : "Management is the science and art of regulating the process of utilization of human resources and other resources effectively and efficiently to achieve one goal." Meanwhile, according to (Zainal et al., 2016) definition of management is: "Management contains 3 (three) terms, namely the first management as a process, both the management as a collectivity of people who perform the activity of management, and the third is management as a science."

\section{Marketing}

In general, marketing includes the activities which are very broad such as sales activity, marketing research, planning of distribution channels, planning the the price policy, promotion policy, and others. Where activity is shown to be able to identify the desires of consumers of the target market, and how to satisfy them more effectively and efficiently compared to its competitors. Below is described the definition of marketing from some experts, among them are: According to (Zhang, 2015) marketing is "Marketing is about identifying and meeting human and social needs. One of the shortest good definitions of marketing is meeting needs profitably". While marketing according to (Segal \& Podoshen, 2013) is "Marketing is an organizational function and set of process for creating communicating and delivering value to customers and for managing customer relationships in that benefit the organization andils stakeholders".

\section{Services}

According to (Shankarmahesh, 2006): "A Service is any act or performance that one party can offer to another that is essentially intangible and does not result in ownership of anything. It's production may or may not be tied to a physical product". The intention is that the service is an action / performance that is offered by one party to the other party in 
principle intangible and does not cause any transfer of ownership. Its production can be related and also not related to a physical product.

Meanwhile (Shankarmahesh, 2006) defines services that: "An act or performance that creates benefits for customers by bringing about a desired change in or on be half of the recepient". (Mickelsson \& Lipkin, 2015) define services as follows: "An activity which some elements of intangibility associated with it, which involves some interaction with customers or with property in their possession, and does not result in a transfer of ownership".

\section{Patient Satisfaction}

According to (Mboi, 2015) states that customer satisfaction is the core of the achievement of the long-term profitability. Satisfaction is difference between expectations and performance (actual received). If expectations are high, while the performance is low, satisfaction will not be achieved. The theory of customer satisfaction is always based on the efforts of the elimination or at least narrow the gab between expectations and performance. The expectations formed of communication is interesting of mouth, personal needs and past experience.

Customer satisfaction according to (Nørgaard, 2011) "Satisfaction is a person's feelings of pleasure or disappointment resulting from company a product's perceived performance (or Outcame) in relation to his or her expectations." From these explanations show that, the results of the comparison between what is expected with what is perceived of a product will produce a sense of satisfied or disappointed customers.

\section{Patients Trust}

The concept of trust became an issue that is popular in the field of marketing with the advent of the orientation of the relational in marketing activities (Council, 2008). Relationship marketing is an important concept in strategic marketing, as it is said (Francis, 2013) that: "Relational marketing is one of the streams of conceptual and empirical work in strategic marketing. Relational marketing is defined as the identification, establishment, maintenance, enhancement, modification and termination of relationship with customers/ consumers to create value for the customer and profit for organization by a series of orgoing exchanges that have both a history an a future".

Customer a successful company is a company that is able to establish a relationship long-term with its customers. Relationship long-term mean customers who are loyal and have a high retention rate to keep in touch with the company to meet the needs and desires are satisfied. The focus of relationship marketing is to gain and retain customers. It means treat them well, improve the core services (core service) company through the addition of value, and the most important thing is to give service that is needed by each individual (Pearson \& Raeke, 2000). Basically the customer be at the core of relationship marketing.

Trust is the foundation of the business (Leimeister et al., 2005). The trust has an important role in the marketing industry. The dynamics of the business environment quickly forced the marketing companies to look for ways that are more creative and flexible to adapt. To survive in such a situation, the company will seek creative ways through the establishment of a relationship that is collaborative with the customers (Francis, 2013). Trust is considered as the most important way in building and maintaining relationships with customers in the long term. Trust is essential for building and maintaining long-term relationships (Rolfe et al., 2014). 


\section{FRAMEWORK, THE HYPOTHESIS \\ Framework}

Health center as one type of First-Level Health Facilities (FKTP) has an important role in the national health system, in particular the subsystem of health services as a public service facility which has the task of organizing health services with comprehensive services through the efforts of disease prevention, health coaching, treatment of diseases and recovery of health conditions (Widada et al., 2017).

This study provides rationale for the analysis of problems and the determination of the concept of research as well as the variables in the study, namely service quality, customer satisfaction, and customer confidence in the service.

Based on the framework influence the provision of services to the satisfaction of the patient as well as its implications for patient confidence, then it can be described as follows:

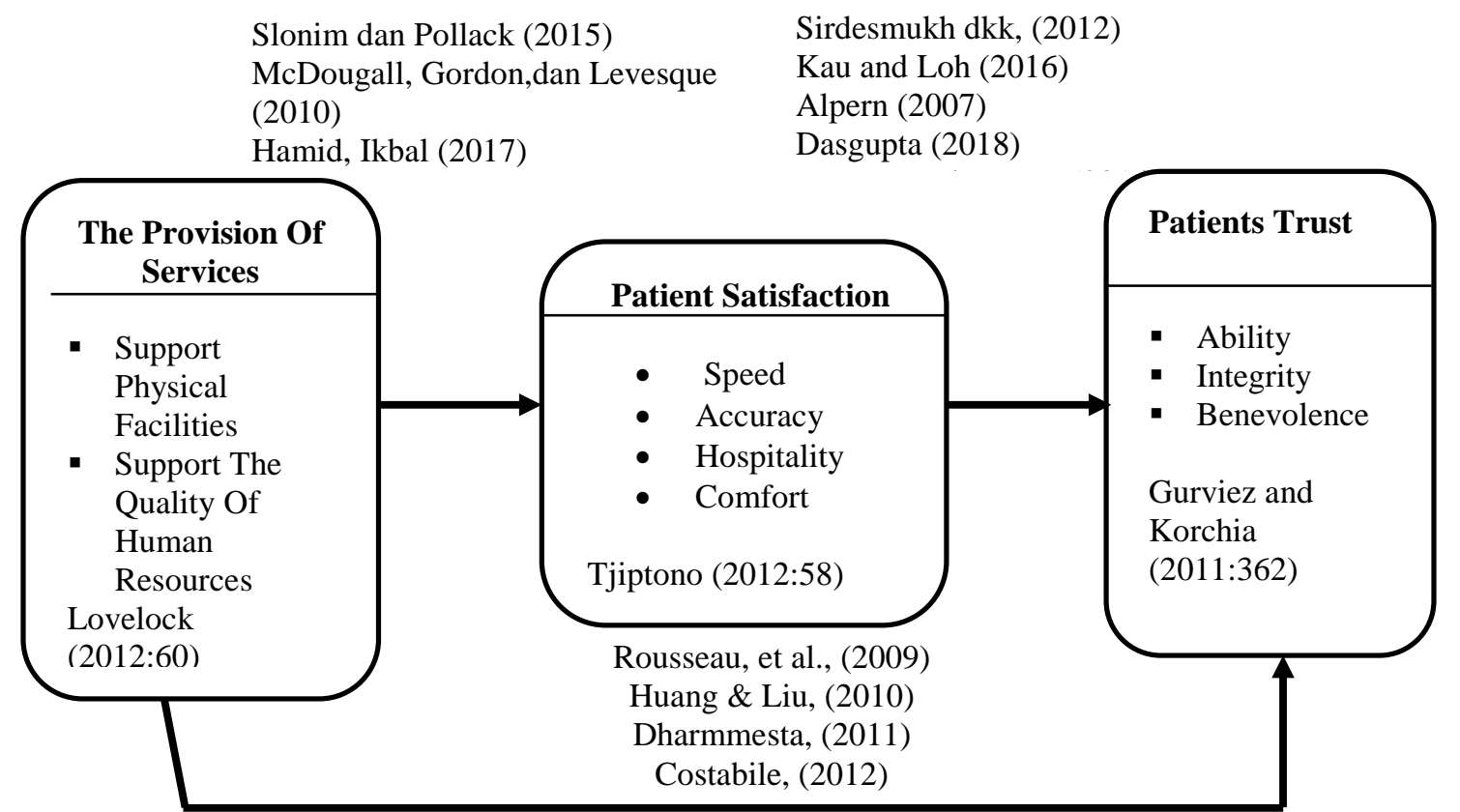

Figure 1

Research Paradigm

\section{Hipotesis Penelitian}

Based on the results of previous research and based on the theories of the experts above, the writer put forward the hypothesis research as follows :

1. Service delivery influence patient satisfaction.

2. The provision of services influence the trust of patients.

3. Patient satisfaction affect patient trust.

4. Service delivery influence patient satisfaction and its implication on the confidence of the patient. 


\section{RESEARCH METHODOLOGY}

This research uses quantitative approach with descriptive statistical analysis techniques and verification. The analysis technique is descriptive statistics used to analyze the data by describing the data that has been collected as is without intending to make a conclusion that applies to general or generalization (Sugiyono, 2013). The nature of the verification is to test the truth of a hypothesis, research using test statistics that are relevant are implemented through field data collection. This study was conducted to determine the effect of the delivery of services to the customer satisfaction and its implications for the trust of the patient based on the quantitative data collected through questionnaires distributed to patients in the Clinic Pratama Mitra Sehati, then this data will be carried out the statistical analysis.

The analysis used to consist of two types, namely : (1). Descriptive analysis, especially for qualitative variables and (2). The analysis of the verification, in the form of hypothesis testing by using statistical tests. Quantitative analysis is emphasized to reveal the behaviour of research variables, while analysis of the descriptive/qualitative used to explore the behavior of the causative factors. By using a combination of analytical methods can be obtained by generalizing that is comprehensive.Data analysis used is SEM (Stucture Equation Model).

\section{RESULTS AND DISCUSSION}

Based on the results of the study, the overall conditions of the three research variables can be seen in table 1 below :

Table 1

The Average value, Range of Values and the Criteria of Respondents ' Answers

\begin{tabular}{|c|l|c|c|c|c|c|}
\hline No & \multicolumn{1}{|c|}{ Variable } & average & \multicolumn{2}{c|}{ Interval Value } & Criteria \\
\hline 1 & provision services & 2.62 & 2.61 & $\mathrm{~s} / \mathrm{d}$ & 3.41 & Good Enough \\
\hline 2 & Patient satisfaction & 2.84 & 2.61 & $\mathrm{~s} / \mathrm{d}$ & 3.41 & Quite Satisfied \\
\hline 3 & Patients trust & 2.80 & 2.61 & $\mathrm{~s} / \mathrm{d}$ & 3.41 & Enough To Believe \\
\hline
\end{tabular}

Source : data processed 2019

Based on Table 1 above, where the average value of each variable is in the interval the average value of 2.62 to 2.84 and. Where patient satisfaction is a variable that has the highest average value and the provision of service is the variable that has the average value of the lowest. Nevertheless it can be concluded that the provision of services, patient satisfaction, and patient trust in the health center Purbaratu Tasikmalaya City belongs to the category of good enough.

\section{The influence of the Provision of Services to the Satisfaction of the Patient as well As the Implications on the Trust the Patient}

The stages of testing at the sub-structure is as follows :

$$
\mathrm{Z}=\beta \mathrm{X}_{\mathrm{ZX}}+\beta \mathrm{Y}_{\mathrm{ZY}}+\varepsilon_{1}
$$

Refers to the structure of the relationship of all variables as depicted in figure 1, the obtained picture of the existence of indirect relationship between the provision of services to the trust patients through the patient satisfaction. Based on the results of the data processing program Lisrel 8.8 for the model of indirect relationship are as follows : 


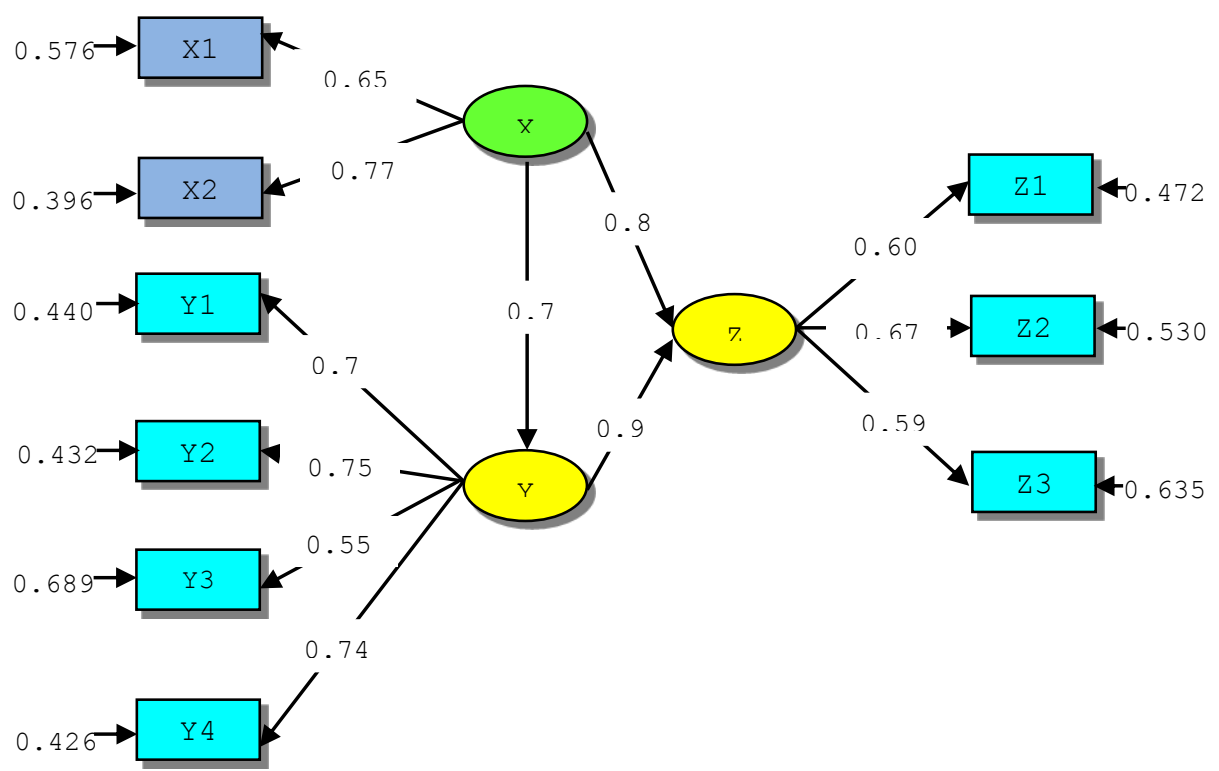

Figure 2

The Influence of The Provision of Services To Patient Satisfaction And Its Implications For Patient Confidence

Source: researchers with the program Lisrel 8.8 (2019)

To determine the influence of direct and indirect service delivery, and patient satisfaction of the patients trust, can be explained as follows:

\section{Indirect Effect}

The indirect effect is the effect of $\mathrm{X}$ on $\mathrm{Z}$ through $\mathrm{Y}$.

Here are the results of the calculation:

$\mathrm{IE}_{\mathrm{ZYX}} \quad: \mathrm{X} \rightarrow \mathrm{Y} \rightarrow \mathrm{Z}=(0.784)(0.927)=0.727$

The magnitude of the influence of the provision of services to the patients trust in the health center Purbaratu Tasikmalaya City via patient satisfaction is at $72.70 \%$.

\section{Direct Effect}

The direct influence, i.e. influence from $\mathrm{X}$ to $\mathrm{Y}$ and $\mathrm{Z}$, and $\mathrm{Y}$ to $\mathrm{Z}$. Here are the results of the calculation :
$\mathrm{DE}_{\mathrm{YX}} \quad: \mathrm{X} \rightarrow \mathrm{Y}=0.784$
$\mathrm{DE}_{\mathrm{ZX}} \quad: \mathrm{X} \rightarrow \mathrm{Z}=0.804$
$\mathrm{DE}_{\mathrm{ZY}} \quad: \quad \mathrm{Y} \rightarrow \mathrm{Z}=0.927$
a. The influence of the direct provision of services to the satisfaction of the patient is equal to 0.784

b. The influence of direct service delivery to the trust of the patient is equal to 0.804

c. The direct influence of patient satisfaction on patient trust is equal to 0.927 


\section{Total Effect}

The total influence is the sum of the provision of services to the satisfaction of the patient either directly or indirectly.

$$
\mathrm{TE}_{\mathrm{YX}}=\mathrm{DE}_{\mathrm{YX}}+\mathrm{IE}_{\mathrm{ZX}}=(0.784)+(0.727)=0.569
$$

Table 2

Recapitulation Of The Results Of Data Processing

\begin{tabular}{|l|c|l|}
\hline \multicolumn{1}{|c|}{ Description } & Variable & \multicolumn{1}{|c|}{ Results } \\
\hline $\begin{array}{l}\text { The value of the Path coefficient Variable independet against an } \\
\text { intervening variable }\end{array}$ & $\mathrm{X}->\mathrm{Y}$ & 0,784 \\
\hline $\mathrm{R}^{2}$ & $\mathrm{X}->\mathrm{Y}$ & $61,46 \%$ \\
\hline $\begin{array}{l}\text { The value of the Path coefficient Variable independet on the } \\
\text { dependent variable }\end{array}$ & $\mathrm{X}->\mathrm{Z}$ & 0,804 \\
\hline $\mathrm{R}^{2}$ & $\mathrm{X}->\mathrm{Z}$ & $64,64 \%$ \\
\hline $\begin{array}{l}\text { The value of the path coefficient an Intervening Variable on the } \\
\text { dependent variable }\end{array}$ & $\mathrm{Y}->\mathrm{Z}$ & 0,927 \\
\hline $\mathrm{R}^{2}$ & $\mathrm{Y}->\mathrm{Z}$ & $85,93 \%$ \\
\hline
\end{tabular}

Source : data processed

\section{The Influence of The Provision Of Services To The Satisfaction Of The Patient}

The results of the calculation showed that the effect of the provision of services to the satisfaction of the patient BPJS Puskesmas Purbaratu City of Tasikmalaya that is equal to $61,46 \%$. This means that the better provision of the services provided, the higher the satisfaction the patients received. And vice versa that the lower the provision of service felt by the patient, the lower the satisfaction the patients received.

The service provided to the customer is a system that consists of two main components, namely service operations and service delivery, (Barbier, 2015) as an operating system service is a system of back room from a product that supports the products/services are assured of reliability and availability. A system of back room supported by the personalpersonal who has expertise core competence/technical core that is not visible to the customer. While the service as a system service delivery system is the delivery of products associated directly with the customers.

The linkage between the delivery of services with perceived value is that the delivery of quality services will increase the value for customers so that it will be able to create satisfaction which ultimately can improve customer loyalty. In line with the opinion of (Sauvé, 2003) revealed that the results of research over the past 30 years show that there are six elements of service quality that are important in a hospital to increase the satisfaction and loyalty of patients, namely : safety, effectiveness, equity, timeliness, focus to patients, and efficiency in a hospital. the next (Duddle \& Boughton, 2009), (Hall et al., 2002) states three variables, namely service delivery system, quality of relational services and perceived value significantly affect customer satisfaction as well as interest in the use of return in the future.

\section{The Influence of The Provision Of Services To Trust Patients}

The results of the calculation showed that the effect of the provision of services to the trust BPJS against the health center Purbaratu City of Tasikmalaya that is equal to $64,64 \%$. A positive value indicates that the higher the provision of services felt by the patient in consuming the service, then the confidence of the patient to the Puskesmas is also increasing. 
And vice versa that the lower the provision of service felt by the patient in consuming the service, then the confidence of the patient to the health center also is getting low.

Customer confidence is a construct that stands on its own and is influenced by service quality (Halsall \& Vernetson, 2005). Service quality can also affect the confidence of customers (Zeithaml, 2000) and affect customer loyalty indirectly through satisfaction (Parasuraman et al., 2005). The quality of service encourage the customer to commitment to products and services of a company so the impact to increase the market share of a product. Quality service is crucial in maintaining customer confidence in a long time. Companies that have service that is superior will be able to maximize the financial performance of the company. The high level of competition, will lead to customers facing more alternative products, prices and quality vary, so customers will always look for the value that is considered the most high of some of the products (Zeithaml et al., 2002). Low quality will lead to dissatisfaction on the customer, not only the customers who eat in the restaurant but also have an impact on other people. Because dissatisfied customers will tell you the most a little to 15 other people. The impact, prospective customers will drop the choice to competitors (Shankarmahesh, 2006).System improvement efforts service quality, will be much more effective for the sustainability of the business.

\section{The Influence of Patient Satisfaction On Patient Trust}

The calculation results show that the influence of patient satisfaction on trust BPJS patients to the health center Purbaratu City of Tasikmalaya that is equal to 85,93\%. A positive value indicates that the higher the patient satisfaction customer perceived in consuming service, then the confidence of the patient to the Puskesmas is also increasing. And vice versa that the lower the patient satisfaction which is felt by the patient in consuming the services, then the confidence of the patient to the health center also is getting low. Trust is the belief of the parties regarding the intent and behavior of the other party. Thus consumer trust is defined as the expectation of the consumer that the service provider can be trusted or relied upon in fulfilling his promise (Wibowo, 2014).

Trust is considered as an action, behavior or orientation, a relationship (Thom et al., 2004). While others still think that trust is a natural feeling or a belief, a belief which a person willing to act (Hesse et al., 2005), or an option (Pearson \& Raeke, 2000). Trust has been described as a cognitive action (for example, the form of opinion or prediction that something will happen or someone will behave in a certain way), affective (for example a matter of feeling) or conative (e.g. the issue of choice or desire). There are some 4 form of trust, namely trust-based objectives, the trust-based calculation, trust based knowledge, and reward-based trust. Trust is obviously very beneficial and important to build a relationship, despite being a party that is trusted is not easy and requires a joint effort. The following factors contribute to the formation of trust (Rolfe et al., 2014), namely the values, dependence on others, open communication and regular, and behave for opportunis. Commitment and trust are the two most important components of a long-term relationship between the company and the partner exchange them.

(Halsall \& Vernetson, 2005) stated that there is a positive relationship between customer satisfaction and service quality. as well as customer satisfaction and trust. This study provides rationale for the analysis of problems and the determination of the concept of research as well as the variables in the study, namely service quality, customer satisfaction, and customer confidence in the service.

\section{The Influence of The Provision Of Services To The Trust Patients Through Patient Satisfaction}


The better the provision of services provided the health center Purbaratu Tasikmalaya City the better satisfaction of the patients received that will ultimately have an impact on the increased confidence of the patient to the health center Purbaratu the City of Tasikmalaya. According to (Hazfiarini \& Ernawaty, 2016) the quality of services as a measure of how good the level of service given able to fit with customer expectations. So quality services can be realized through the fulfillment of the wishes and needs of customers as well as timeliness of delivery to balance customer expectation. From the definition was that there are two main factors that affect the quality of service is the expected service and perceived service. When services are received or perceived in accordance with the services expected then service quality is perceived good. Conversely, if the expected service is not in accordance with the services received, then the perception of the perceived poor quality of service. Therefore whether or not the quality of the services depends on the service provider's ability to meet the expectations of its customers consistently.

As a health care institution owned by the government, one hospital, the quality of service into the public spotlight, thus improving the quality of health services becomes a demand that must be implemented. Increase the quality of service both in terms of physical facilities, the available tools and human resources both in quantity and quality, this will affect customer satisfaction. Thus hospitals must give priority to the satisfaction of his patients as users of services.

Trust is an important problem in human relations. (Yellen et al., 2002) shows that trust means one considers the transaction partner who is reliable and honest and have confidence in it. (Downey-Ennis, 2011) suggest that trust is the hope of the cognitive or the emotional point of view. This is also the behavior of the risk or the desire to engage in behavior that is said above. If the trusted object is an organization, trust is defined as the dependence of customers on service quality and reliability offered by the organization (Batbaatar et al., 2017). Trust is a very important factor in the competitive business environment of today. Trust in business relationships helps reduce the risk of the business (Ramseook-Munhurrun et al., 2010). (Godey et al., 2016) show that mutual trust is influenced by the identification of the psychological, image, and reputation that is felt between the supplier and the buyer. (Zeffane et al., 2011) considers the definition of trust comes before and after the transaction. The trust introduced before the transaction directly influence satisfaction after the transaction, while the confidence displayed after the transaction is directly influenced trust afterwards.

(Cai \& Pavlou, 2002) concluded in their research that in the empirical studies related, customer trust leads to four results : (1) the customer is satisfied with the sales force, the company, and the transaction; (2) the customer has a positive attitude towards the commodities purchased and the loyalty and support to the company; (3) customer trust further increased the interest in the purchase; and (4) the customer will choose to buy the commodities offered by a company they trust.

According to the academics, customer confidence is a construct that stands on its own and is influenced by service quality (Hennig-Thurau et al., 2002). Service quality can also affect the confidence of customers (Román \& Iacobucci, 2010) and affect customer loyalty indirectly through satisfaction (Ou et al., 2014). Quality service is crucial in maintaining customer confidence in a long time. Companies that have service that is superior will be able to maximize the financial performance of the company. The high level of competition, will lead to customers facing more alternative products, prices and quality vary, so customers will always look for the value that is considered the most high of some of the (Hansemark \& Albinsson, 2004). Low quality will lead to dissatisfaction on the customer, not only the 
customers who eat in the restaurant but also have an impact on other people. Because dissatisfied customers will tell you the most a little to 15 other people. The impact, prospective customers will drop the choice to competitors (Hansemark \& Albinsson, 2004).

\section{CONCLUSION}

(1) The provision of services according to the patient BPJS Puskesmas Purbaratu the Town of Tasikmalaya, which consists of the dimensions of support physical facilities and support quality human resources are interpreted in the criteria quite well. There are plenty of indicators is suggested to be the focus of improvement of parking facilities, availability of room consultations to prospective patients and patients, and the quality of the room where the patient is treated.

(2) Patient satisfaction BPJS Puskesmas Purbaratu the Town of Tasikmalaya, which consists of the dimensions of speed, accuracy, hospitality and comfort are interpreted in the criteria quite well. There are plenty of indicators is suggested to be the focus of improvement, namely the friendliness of the nurse when serving the patient, the procedure to get service, and doctors are less quick response in serving the patients.

(3) Trust BPJS patients to the health center Purbaratu the Town of Tasikmalaya, which consists of the dimensions of ability (ability), integrity (integrity) and benevolence (benevolence) is interpreted in the criteria quite well. There are plenty of indicators is suggested to be the focus of improvement are less trusting of doctors willing to take the time to consult, are less trusting of the ability of officers in utilizing medical equipment, and lack of trust to the honesty of the medical officers and paramedics in conveying information.

(4) There is the influence of the provision of services to the satisfaction of the patient, this indicates that the variable provision of the service can be pushed against the increased satisfaction of the patient.

(5) There is the influence of the provision of services to trust patients, this indicates that the variable provision of the service can be pushed against the increased confidence of the patient.

(6) There is the influence of patient satisfaction on patient trust, it is shown that the variable of patient satisfaction can be pushed against the increased confidence of the patient.

(7) There is the effect of the service on patient trust through satisfaction. The better the provision of services provided the health center Purbaratu the Town of Tasikmalaya, the better the satisfaction of patients who received that ultimately will have an impact on the increased confidence of the patient to the health center Purbaratu the City of Tasikmalaya.

\section{REFERENCE}

Barbier, E. B. (2015). Ecosystem services. In Handbook on the Economics of Natural Resources. https://doi.org/10.4337/9780857937568.00020

Batbaatar, E., Dorjdagva, J., Luvsannyam, A., Savino, M. M., \& Amenta, P. (2017). Determinants of patient satisfaction: A systematic review. In Perspectives in Public Health. https://doi.org/10.1177/1757913916634136

Cai, L., \& Pavlou, P. (2002). Custumer Relationship Managemen.com: A Cross-Cultural 
Empirical Investigation Of Electronic Comerce. Americas Conference on Information System.

Council, N. and M. (2008). The code : Standards of conduct, performance and ethics for nurses and midwives. Group Analysis. https://doi.org/10.1177/053331647901200106

Downey-Ennis, K. (2011). Patient satisfaction. In International journal of health care quality assurance. https://doi.org/10.5005/jp/books/14122_132

Duddle, M., \& Boughton, M. (2009). Development and psychometric testing of the Nursing Workplace Relational Environment Scale (NWRES). Journal of Clinical Nursing. https://doi.org/10.1111/j.1365-2702.2008.02368.x

Francis, R. (2013). Report of the Mid Staffordshire NHS Foundation Trust Public Inquiry. In New directions for youth development. https://doi.org/10.1002/yd.20044

Godey, B., Manthiou, A., Pederzoli, D., Rokka, J., Aiello, G., Donvito, R., \& Singh, R. (2016). Social media marketing efforts of luxury brands: Influence on brand equity and consumer behavior. Journal of Business Research. https://doi.org/10.1016/j.jbusres.2016.04.181

Gouws, E., Bryce, J., Pariyo, G., Schellenberg, J. A., Amaral, J., \& Habicht, J. P. (2005). Measuring the quality of child health care at first-level facilities. Social Science and Medicine. https://doi.org/10.1016/j.socscimed.2004.12.019

Hall, M. A., Zheng, B., Dugan, E., Camacho, F., Kidd, K. E., Mishra, A., \& Balkrishnan, R. (2002). Measuring patients' trust in their primary care providers. Medical Care Research and Review. https://doi.org/10.1177/1077558702059003004

Halsall, S., \& Vernetson, T. B. (2005). Performance assessment. In Preparing for Inclusive Teaching: Meeting The Challenges of Teacher Education Reform. https://doi.org/10.4324/9781315464770-16

Hansemark, O. C., \& Albinsson, M. (2004). Customer satisfaction and retention: The experiences of individual employees. Managing Service Quality: An International Journal. https://doi.org/10.1108/09604520410513668

Hazfiarini, A., \& Ernawaty, E. (2016). Indeks Kepuasan Pasien BPJS Kesehatan Terhadap Pelayanan Rumah Sakit Mata Masyarakat Jawa Timur. Jurnal Administrasi Kesehatan Indonesia. https://doi.org/10.20473/jaki.v4i2.2016.77-85

Hennig-Thurau, T., Gwinner, K. P., \& Gremler, D. D. (2002). Understanding Relationship Marketing Outcomes: An Integration of Relational Benefits and Relationship Quality. Journal of Service Research. https://doi.org/10.1177/1094670502004003006

Hesse, B. W., Nelson, D. E., Kreps, G. L., Croyle, R. T., Arora, N. K., Rimer, B. K., \& Viswanath, K. (2005). Trust and Sources of Health Information. Archives of Internal Medicine. https://doi.org/10.1001/archinte.165.22.2618

Kemenkes RI 2012. (2012). Profil Kesehatan Indonesia 2011. In Profil Kesehatan Indonesia.

Leimeister, J. M., Ebner, W., \& Krcmar, H. (2005). Design, implementation, and evaluation of trust-supporting components in virtual communities for patients. Journal of Management Information Systems. https://doi.org/10.1080/07421222.2005.11045825 
Mangkunegara, A. A. A. P. (2003). Manajemen Sumber Daya Manusia Perusahaan. In Remaja Rosdakarya. https://doi.org/10.1038/cddis.2011.1

Marwansyah. (2012). Manajemen Sumber Daya Manusia. Manajemen Sumber Daya Manusia.

Mboi, N. (2015). Indonesia: On the way to universal health care. Health Systems and Reform. https://doi.org/10.1080/23288604.2015.1020642

Mickelsson, J., \& Lipkin, M. (2015). Custumer Activity: A Research Agenda. In The Nordic School: Service Marketing and Management for the Future.

Nørgaard, B. (2011). Communication with patients and colleagues. Danish Medical Bulletin.

Ou, Y. C., de Vries, L., Wiesel, T., \& Verhoef, P. C. (2014). The Role of Consumer Confidence in Creating Customer Loyalty. Journal of Service Research. https://doi.org/10.1177/1094670513513925

Parasuraman, A., Zeithaml, V. A., \& Malhotra, A. (2005). E-S-QUAL a multiple-item scale for assessing electronic service quality. Journal of Service Research. https://doi.org/10.1177/1094670504271156

Pearson, S. D., \& Raeke, L. H. (2000). Patients' trust in physicians: Many theories, few measures, and little data. In Journal of General Internal Medicine. https://doi.org/10.1046/j.1525-1497.2000.11002.x

Ramseook-Munhurrun, P., Lukea-Bhiwajee, S., \& Naidoo, P. (2010). Service Quality in the Public Service. International Journal of Management and Marketing Research.

Rolfe, A., Cash-Gibson, L., Car, J., Sheikh, A., \& Mckinstry, B. (2014). Interventions for improving patients' trust in doctors and groups of doctors. In Cochrane Database of Systematic Reviews. https://doi.org/10.1002/14651858.CD004134.pub3

Rolindrawan, D. (2015). The Impact of BPJS Health Implementation for the Poor and Near Poor on the Use of Health Facility. Procedia - Social and Behavioral Sciences. https://doi.org/10.1016/j.sbspro.2015.11.073

Román, S., \& Iacobucci, D. (2010). Antecedents and consequences of adaptive selling confidence and behavior: A dyadic analysis of salespeople and their customers. Journal of the Academy of Marketing Science. https://doi.org/10.1007/s11747-009-0166-9

Sauvé, P. (2003). Services. In Regionalism and the Multilateral Trading System. https://doi.org/10.1787/9789264101371-en

Segal, B., \& Podoshen, J. S. (2013). An examination of materialism, conspicuous consumption and gender differences. International Journal of Consumer Studies. https://doi.org/10.1111/j.1470-6431.2012.01099.x

Shankarmahesh, M. N. (2006). Consumer ethnocentrism: An integrative review of its antecedents and consequences. In International Marketing Review. https://doi.org/10.1108/02651330610660065

Sugiyono. (2013). Metode Penelitian Pendidikan Pendekatan Kuantitaif, Kualitatif, dan R\&DSugiyono. 2013. "Metode Penelitian Pendidikan Pendekatan Kuantitaif, Kualitatif, dan R\&D." Metode Penelitian Pendidikan Pendekatan Kuantitaif, Kualitatif, dan R\&D. 
https://doi.org/10.1. In Metode Penelitian Pendidikan Pendekatan Kuantitaif, Kualitatif, dan $R \& D$.

Suprianto, A., \& Mutiarin, D. (2017). EVALUASI PELAKSANAAN JAMINAN KESEHATAN NASIONAL. Journal of Governance and Public Policy. https://doi.org/10.18196/jgpp.4172

Thom, D. H., Hall, M. A., \& Pawlson, L. G. (2004). Measuring patients' trust in physicians when assessing quality of care. In Health Affairs. https://doi.org/10.1377/hlthaff.23.4.124

Wibowo, H. A. (2014). Pengaruh Kompetensi Operasional, Kearifan Operasional, Dan Orientasi Pemecahan Masalah Karyawan Lini Depan Terhadap Kepercayaan Dalam Membentuk Loyalitas Konsumen. Jurnal Manajemen.

Widada, T., Pramusinto, A., \& Lazuardi, L. (2017). Peran Badan Penyelenggara Jaminan Sosial (Bpjs) Kesehatan Dan Implikasinya Terhadap Ketahanan Masyarakat (Studi Di Rsud Hasanuddin Damrah Manna Kabupaten Bengkulu Selatan, Provinsi Bengkulu). Jurnal Ketahanan Nasional. https://doi.org/10.22146/jkn.26388

Yellen, E., Davis, G. C., \& Ricard, R. (2002). The Measurement of Patient Satisfaction. Journal of Nursing Care Quality. https://doi.org/10.1097/00001786-200207000-00005

Zainal, F. Y., Rahim, N. A., Rivai, A., \& Erixno, O. (2016). Fault detection and isolation for water-pump system with signal-based approach using SCADA. IET Conference Publications. https://doi.org/10.1049/cp.2016.1350

Zeffane, R., A Tipu, S., \& Ryan, J. C. (2011). Communication, Commitment \& Trust: Exploring the Triad. International Journal of Business and Management. https://doi.org/10.5539/ijbm.v6n6p77

Zeithaml, V. A. (2000). Service quality, profitability, and the economic worth of customers: What we know and what we need to learn. Journal of the Academy of Marketing Science. https://doi.org/10.1177/0092070300281007

Zeithaml, V. A., Parasuraman, A., \& Malhotra, A. (2002). Service quality delivery through web sites: A critical review of extant knowledge. In Journal of the Academy of Marketing Science. https://doi.org/10.1177/009207002236911

Zhang, Y. (2015). The Impact of Brand Image on Consumer Behavior: A Literature Review. Open Journal of Business and Management. https://doi.org/10.4236/ojbm.2015.31006 